\title{
INTER-ANNUAL VARIABILITY IN FLOWERING OF ORCHIDS: LESSONS LEARNED FROM 8 YEARS OF MONITORING IN A MEDITERRANEAN REGION OF FRANCE
}

\author{
HÉLENE VOGT-SCHILB ${ }^{1,2}$, PHILIPPE GENIEZ ${ }^{3}$, ROGER PRADEL ${ }^{1}$, \\ FRANCK RICHARD ${ }^{1}$, and BERTRAND SCHATZ ${ }^{1, *}$ \\ ${ }^{1}$ Centre d'Ecologie Fonctionnelle et Evolutive (CEFE), UMR 5175 CNRS, 1919 Route de Mende, 34293 Montpellier, France \\ 2 Biotope, 22 boulevard Maréchal Foch, 34140 Mèze, France \\ ${ }^{3}$ Ecole Pratique des Hautes Etudes, Biogéographie et Ecologie des Vertébrés, Centre d'Ecologie Fonctionnelle et Evolutive (CEFE), \\ UMR 5175 EPHE, 1919 Route de Mende, 34293 Montpellier, France \\ *Corresponding author: bertrand.schatz@cefe.cnrs.fr
}

\begin{abstract}
It is important to evaluate the loss of biodiversity caused by global changes. In the case of orchids, it is still unclear how long the monitoring duration should be chosen in order to achieve a good compromise between the reliability of the orchid dynamics recorded and sampling duration (e.g. years of monitoring). This study aims to propose a method of monitoring orchids. Using a large database, we investigated the inter-annual variability in flowering of orchids in a French Mediterranean region. The database includes an 8-year-long study (2006-2013) of 47 species at 26 locations in three different types of habitats. The number of individual plants that flowered per species varied significantly between years, but not the number of species. Depending on habitat, two to four years were needed to observe the total number of species per location. Therefore, in Mediterranean regions a one-year-study seems to be insufficient to produce reliable results.
\end{abstract}

Keywords: orchid community, diachronic studies, orchid monitoring, similarity index, conservation

\section{Introduction}

In the era of global change that deeply affects organisms on our planet (Parmesan 2006), there is an increasing urgency to evaluate the loss in biodiversity (Barnosky et al. 2011; Thuiller et al. 2011). In order to propose appropriate conservation strategies, it is essential for conservation biologists to precisely evaluate shifts in communities. Limiting our topic in orchids, it has been well acknowledged that orchids are ideal models to evaluate the impact of global change on biodiversity. First of all, they show clear and fast responses to environmental changes, including a current and well documented decline in occurrence or population size (Whigham and Willems 2003; Schatz et al. 2013). Then, many orchids are emblematic species (Cribb et al. 2003) and there is an increasing need to study them with the aim of conservation. Thirdly, they show well-documented patterns of endemism and rarity (Bournérias and Prat 2005; Dusak and Prat 2010).

The availability of long-run data or diachronic studies on the distribution of orchids provides opportunities to document temporal variation in communities (Jacquemyn et al. 2005; Kull and Hutchings 2006). These studies enable us to predict response of organisms to future environmental changes. However, there is a lack of standardized methods of recording and analyzing the data (Kati et al. 2004; Archaux et al. 2009). As a result, it is necessary to document the natural variability in the life-history traits of species (e.g. frequency of flowering) and to develop of sampling methods suitable to monitor orchids.
At the species scale, several studies have shown that the number of flowering individuals varied from year to year in response to climatic fluctuations (Tamm 1991; Sieg and King 1995; Wells et al. 1998; Tali 2002; Oien and Moen 2002; Brzosko 2003; Kindlmann 2003; Hrivnak et al. 2006; Jacquemyn et al. 2007). This inter-annual variability is recorded in several different species of orchids, such as Anacamptis morio (Wells et al. 1998), Dactylorhiza majalis (Hrivnak et al. 2006), D. lapponica (Oien and Moen 2002), D. sambucina (Tamm 1991), D. incarnata (Tamm 1991), Gymnadenia conopsea (Oien and Moen 2002), Neotinea ustulata (Tali 2002), Neottia ovata (Tamm 1991), Orchis mascula (Tamm 1991), Platanthera praeclara (Sieg and King 1995), P. bifolia (Brzosko 2003) and Spiranthes spiralis (Jacquemyn et al. 2007). A common characteristic of these studies is that they are all located in northern Europe. Yet, little is known about such variation in Mediterranean species (but see Sirami et al. 2010; Schatz and Geniez 2011). In Mediterranean regions, a high variability in the incidence of flowering of orchids is expected due to the high intra- and inter- annual variation in climate. In the future, longer and more severe drought periods (IPCC 2007; Giorgi and Lionello 2008) may disturb the phenology of orchids. Moreover, the region hosts different types of habitats, e.g. grassland, shrubland and woodland, which may affect flowering patterns of orchids differently.

We investigated the temporal dynamics of orchid assemblages, at both the species and community level (47 species of orchids) in a Mediterranean region of France (Languedoc-Roussillon). This study aims to address the following questions: 
(1) How does the fluctuating Mediterranean climate affect flowering patterns of orchids?

(2) Are there differences in inter-annual flowering of orchids between habitat types?

We documented the inter-annual variations in flowering patterns (e.g. number in flowering individuals and probability of presence) of orchids in order to provide a framework for future monitoring in this region.

\section{Materials and Methods}

\section{Study sites}

Study sites are situated in the North of the Languedoc-Roussillon region in southern France $\left(43^{\circ} 17^{\prime} 31^{\prime \prime} \mathrm{N}-44^{\circ} 17^{\prime} 31^{\prime \prime} \mathrm{N}, 3^{\circ} 05^{\prime} 27^{\prime \prime} \mathrm{E}-3^{\circ} 50^{\prime} 41^{\prime \prime} \mathrm{E}\right)$. At these sites, the climate is of Mediterranean type with annual precipitation ranging from $950 \mathrm{~mm}$ to $1350 \mathrm{~mm}$ (Debussche and Escarré 1983). Air temperature varies from $0{ }^{\circ} \mathrm{C}$ in winter to $28^{\circ} \mathrm{C}$ in summer (Sirami et al. 2010). We sampled at 26 locations, where many species with patchy distributions co-occurred. Three types of habitat were distinguished, corresponding to three stages of succession, hereafter called "grassland" $(\mathrm{n}=10)$, "shrubland" $(\mathrm{n}=8)$ and "woodland" $(\mathrm{n}=8)$. We excluded locations that experienced high levels of disturbance, e.g. intensive tree cutting and grazing. The sampled locations differed in area, ranging from $500 \mathrm{~m}^{2}$ to $2000 \mathrm{~m}^{2}$. In each location, yearly orchid inventory was always carried out in the same area so that outcomes between inventories can be compared.

The study was conducted for eight consecutive years, from 2006 to 2013. In each year, all the flowering individuals were recorded at each location during the same period (between March and July). In total, 47 species of orchids were included in this study. A full list of the species studied is given in Table S1.

\section{Species traits}

Species traits were not measured in the field, but based on the information available in the literature (Bournérias and Prat 2005). The traits included:

1. Number of species of pollinators and mycorrhizal symbionts. They were classified as either a specialist ( 1 species), an intermediate ( $2-5$ species) or a generalist (more than 5 species).

2. Flower morphology. We considered the number of flowers, the size of the inflorescence (mean in $\mathrm{cm}$ ) and plant height (mean in $\mathrm{cm}$ ).

3. Phenology. We considered the duration of flowering (mean in months) and the flowering period (mean in terms of particular months).

\section{Data analysis}

We used Wilcoxon or Kruskal-Wallis tests, i.e. two non-parametric tests, to investigate the effect of year sampled on the variability in the presence and number of flowering individuals. For each median, we calculated the confidence interval (IC), as $\left[1.57 \times\left(Q_{3}-Q_{1}\right)\right] / n^{0.5}$, where, $Q_{1}$ and $Q_{3}$ are the 25 th and 75th percentile of the data, respectively; and $n$ is the number of observations (Chambers et al. 1983).

We averaged the number of species per location and the number of flowering individuals per species and location. Concerning the inter-annual variability between species, we calculated the probability of presence for each species, as the ratio of the number of years when the species was recorded divided by the total number of years monitored, i.e. eight years. We considered that an absence of a record in one or several years did not mean death of an individual, but flowering dormancy. We used Jaccard's similarity index (Jaccard 1901) to determine how similar the species composition was between pairs of consecutive years. The similarity index was calculated as $c /(a+b-c)$, where $a$ is the total number of species in one year; $b$ is the total number of species recorded in the following year; and $c$ is the number of species in common found in both of years (Jaccard 1901). In regard to the number of records, we applied the same similarity index. In this case, the similarity index was equal to the minimum recorded number of flowering individuals divided to the maximum recorded number of flowering individuals between two consecutive years. To compare the similarity index between species, we only considered species that occurred at least at five locations in order to augment the spatial representativeness of the study site.

We used a principal component analysis in order to investigate the relationship between inter-annual variability of flowering (index of similarity and probability of presence) and traits of species. We investigated the species-time relationships using an accumulation curve of species recorded at the site level. We calculated the ratio of the cumulated number of species recorded and the maximum number of species recorded at the same location between 2006 and 2013. This process was repeated for each pair of successive years (e.g. 2007 and 2008, i.e. seven possibilities) and each location.

All analyses were performed using R software ( $\mathrm{R}$ development core team, version 2.15.0). For the principal component analyses, we used the package FactoMineR (Husson et al. 2007).

\section{Results}

\section{Inter-annual variability in flowering at community level}

The number of species recorded per location did not differ significantly between years (Kruskal-Wallis test, $K=3.64, p>0.05$ ), with the median varying slightly, from $5 \pm 1.23$ (Median \pm IC, idem for all the following cases) in 2011 to $6.5 \pm 1.85$ in 2010 (Wilcoxon test, $W=417$, $p>0.05$, Fig. 1A). The median of Jaccard-similarity index between consecutive years was $0.94 \pm 0.02$ for all locations, meaning that the species composition differed 
Table 1 Median \pm confidence interval of Jaccard-similarity index for pairs of consecutive years for all locations and three habitats. Based on Wilcoxon non-parametric test, different letters indicate a significant difference in the Jaccard similarity index between different pairs of consecutive years for a particular habitat. $\mathrm{N}$ is the number of locations.

\begin{tabular}{|c|c|c|c|c|c|c|c|c|c|c|c|c|}
\hline & \multicolumn{3}{|c|}{ All locations } & \multicolumn{3}{|c|}{ Grassland } & \multicolumn{3}{|c|}{ Shrubland } & \multicolumn{3}{|c|}{ Woodland } \\
\hline$N$ & & 26 & & & 10 & & & 8 & & & 8 & \\
\hline 2006 vs 2007 & 0.77 & \pm 0.11 & $\mathrm{a}$ & 0.77 & \pm 0.10 & $\mathrm{a}$ & 0.92 & \pm 0.27 & $a b$ & 0.69 & \pm 0.18 & a \\
\hline 2007 vs 2008 & 0.97 & \pm 0.05 & bd & 1.00 & \pm 0.03 & bc & 0.83 & \pm 0.14 & a & 0.97 & \pm 0.25 & $a b c$ \\
\hline 2008 vs 2009 & 1.00 & \pm 0.05 & bc & 1.00 & \pm 0.00 & $\mathrm{~b}$ & 1.00 & \pm 0.02 & $b$ & 0.8 & \pm 0.12 & $a b$ \\
\hline 2009 vs 2010 & 1.00 & \pm 0.00 & c & 1.00 & \pm 0.00 & $b c$ & 1.00 & \pm 0.02 & b & 1.00 & \pm 0.00 & c \\
\hline 2010 vs 2011 & 0.77 & \pm 0.07 & $\mathrm{ad}$ & 0.85 & \pm 0.10 & $\mathrm{a}$ & 0.69 & \pm 0.11 & a & 0.75 & \pm 0.11 & $a b$ \\
\hline 2011 vs 2012 & 0.88 & \pm 0.07 & $b$ & 0.87 & \pm 0.11 & $\mathrm{ac}$ & 0.94 & \pm 0.09 & $a b$ & 0.87 & \pm 0.12 & $a b c$ \\
\hline 2012 vs 2013 & 0.97 & \pm 0.05 & $b$ & 1.00 & \pm 0.00 & $\mathrm{~b}$ & 0.81 & \pm 0.12 & a & 0.92 & \pm 0.08 & bc \\
\hline Total & 0.94 & \pm 0.02 & & 1.00 & \pm 0.03 & & 0.87 & \pm 0.06 & & 0.88 & \pm 0.06 & \\
\hline
\end{tabular}

by $6 \%$ between consecutive years (Table 1). The Jaccard-similarity index differed significantly between habitats $\left(p<0.05^{\star}\right)$ and the medians were $1 \pm 0.03,0.87 \pm 0.06$ and $0.88 \pm 0.06$ for grassland, shrubland and woodland, respectively (Table 1 ).

For the 47 species of orchids studied the average number of flowering individuals per species and location differed between years (Kruskal-Wallis test, $K=24.75$, $\left.p<0.001^{* * *}\right)$, with the median varying significantly from $5.2 \pm 3.4$ individuals in 2011 to $28 \pm 10.7$ individuals in 2010 (Wilcoxon test, $W=1619.5, p<0.001^{* * *}$, Fig. 1B). The similarity index of the number of flowering individuals between two consecutive years did not differ between habitats $(p>0.05)$.

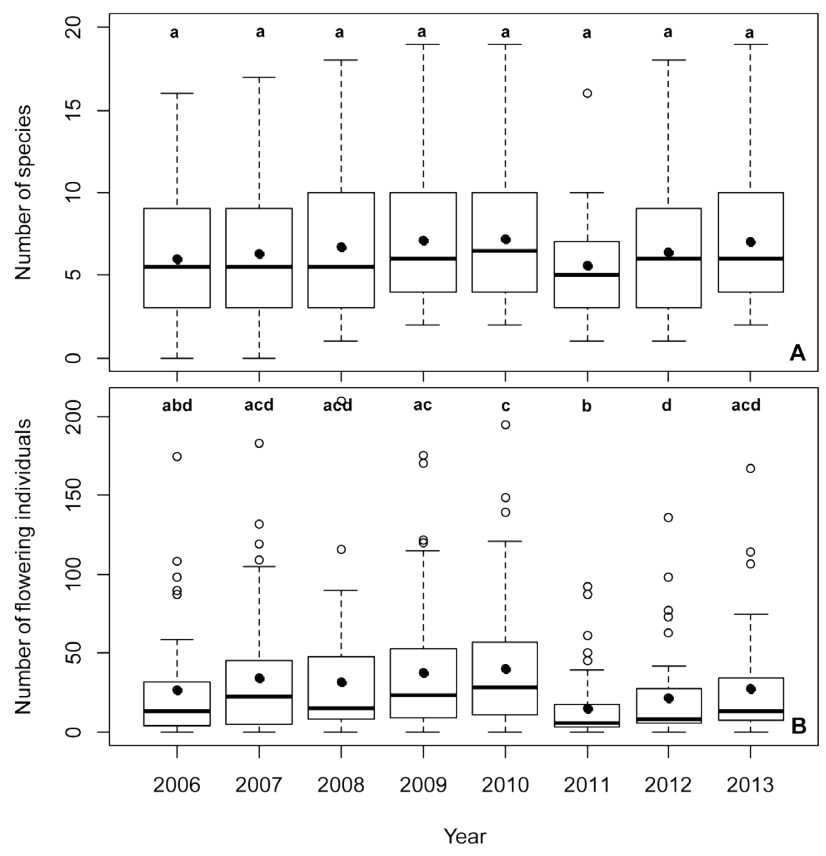

Fig. 1 Boxplots of $(A)$ the average number of species per location and $(B)$ the average number of flowering individuals per species and location recorded per year. Black points correspond to $(A)$ the mean of the number of species per location or $(B)$ the number of flowering individuals per species. Different letters indicate a significant difference based on Wilcoxon non-parametric test. Significant codes: ${ }^{*}=p<0.05$, ${ }^{* *}=p<0.01,{ }^{* * *}=p<0.001$.

\section{Inter-annual variability in flowering at species level}

In the eight years of inventory, probability of being present differed significantly between species (Kruskal-Wallis test, $K=69.7, p<0.05^{*}$, Fig. 2A, Table S2). The median of theaverage probability of presence was $0.82 \pm 0.06$ and $0.87 \pm 0.05$ for the 17 species and all the species studied, respectively (Fig. 2B). The probability of presence varied from 0.52 (for Platanthera chlorantha) to 0.98 (for Anacamptis pyramidalis) (Fig. 2A).

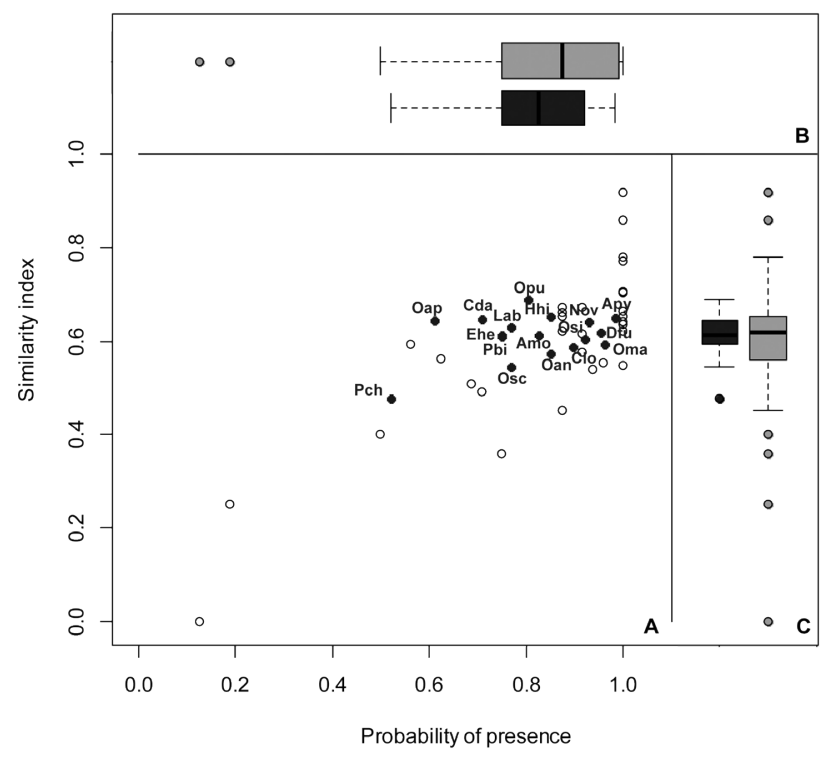

Fig. 2 Plot of the probability of presence and the similarity index of the number of flowering individuals between two consecutive years per year (A). Each point represents the mean probability of presence and similarity index of the orchid species studied that occurred in $\geq 5$ locations (dark-grey points) and $<5$ locations (hollow points). Boxplots of (B) the probability of presence and (C) inter-annual similarity index are depicted for all the species (in light-grey) and for the 17 species that occurred in $\geq 5$ locations (in dark-grey). Abbreviations of species: Amo = Anacamptis morio, Apy = Anacamptis pyramidalis, $\mathrm{Cda}=$ Cephalanthera damasonium, Clo = Cephalanthera longifolia, Dfu = Dactylorhiza fuchsii, Ehe = Epipactis helleborine, Hhi = Himantoglossum hircinum, $\mathrm{Lab}=$ Limodorum abortivum, Nov = Neottia ovata, Oap $=$ Ophrys apifera, Osc = Ophrys scolopax, Oan = Orchis anthropophora, Oma = Orchis mascula, Opu = Orchis purpurea, Osi = Orchis simia, $\mathrm{Pbi}=$ Platanthera bifolia, Pch = Platanthera chlorantha . 
In regard to inter-annual similarity of flowering individuals, there were significant differences between six pairs of species: $P$. chlorantha versus $A$. pyramidalis (Wilcoxon test, $\left.W=74 ; p<0.05^{\star}\right)$, P. chlorantha versus $H$. hircinum (Wilcoxon test, $W=35, p<0.05^{\star}$ ), P. chlorantha versus $O$. purpurea (Wilcoxon test, $W=26, p<0.05^{\star}$ ), $O$. scolopax versus $H$. hircinum (Wilcoxon test, $W=49.5$, $p<0.05^{\star}$ ), O. purpurea versus O. anthropophora (Wilcoxon test, $\left.W=59, p<0.05^{\star}\right)$ and $O$. purpurea versus $O$. scolopax (Wilcoxon test, $W=37, p<0.05^{\star}$ ) (Fig. 2, Table S2). Medians of the averaged similarity index were $0.61 \pm 0.02$ and $0.62 \pm 0.02$ for the 17 species and all of the species studied, respectively (Fig. 2C). The similarity index varied from 0.48 (for Platanthera chlorantha) to 0.70 (for Orchis purpurea) (Fig. 2A).

According to the principal component analysis, the first two factorial axes accounted for $34.89 \%$ (axis 1) and $20.93 \%$ (axis 2) of the total variability, respectively (Fig. S1). The similarity index was negatively related with the duration of flowering. The other traits, e.g. height and number in pollinator species, were neither related to the similarity index, nor to the probability of presence (Fig. S1).

\section{Accumulation in the number of species recorded over time}

The increased percentage in the number of the recorded species that accumulated with time differed between habitats (Fig. 3). One year of sampling captured $87.5 \%$ of the species in grassland, $88.9 \%$ of those in shrubland and $80 \%$ of those in woodland. Significant difference was found between shrubland and woodland (Wilcoxon test, $W=1620.5, p<0.05^{*}$ ), but was absent between grassland and shrubland or between grassland and woodland $(p>0.05)$. The total number of species (median-value of $100 \%$ ) was observed after the 2nd year of sampling for shrubland, the 3 rd year for woodland and the 4 th year for grassland (Fig. 3).

\section{Discussion}

\section{Inter-annual variability in flowering at community level}

We showed that the number of orchid flowering individuals varied conspicuously between years in the Medi terranean region (Fig. 1B). These results are in accordance with the previous findings on the variability in the inter-annual records of orchid numbers in northern Europe (Tamm 1991; Kindlmann and Balounova 1999; Oien and Moen 2002; Tali 2002; Brzosko 2003). Inter-annual fluctuations in orchid abundance are mainly induced by variations in climate, in particular temperature and rainfall (Wells et al. 1998; Pfeifer et al. 2006, 2011). 2006 and 2011 were the driest during the sampling period and the lowest number of individuals per species was recorded in 2011 at most of the study sites. This result indicates that orchids may respond to drought by reducing the number of flowering individuals, as observed by Hutch-ings (2010) in the case of Ophrys sphegodes. We suppose that
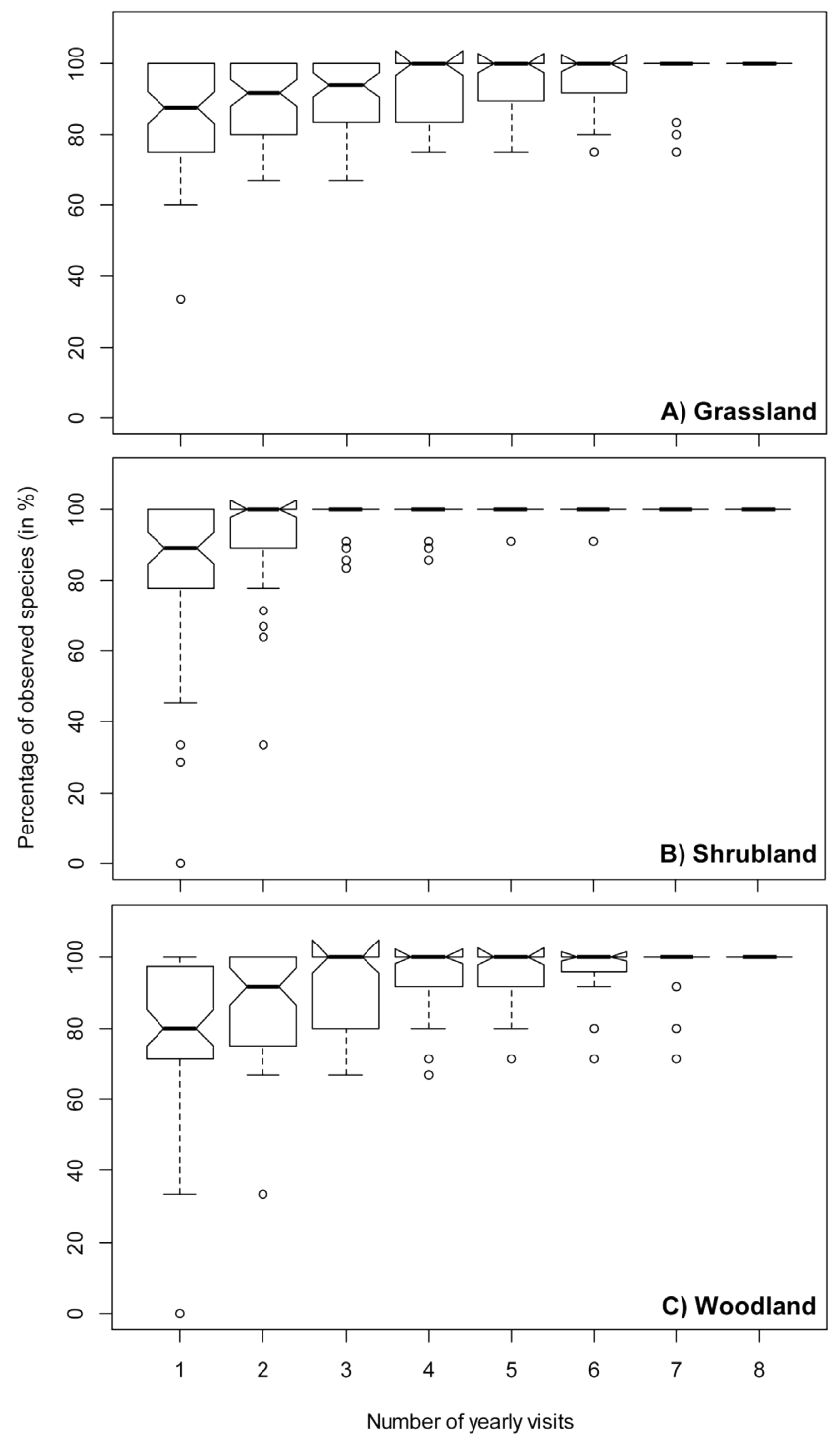

Fig. 3 Boxplot of the cumulative percentage of species recorded in successive yearly inventory, for (A) grassland, (B) shrubland and (C) woodland. A non-overlapping of the notches of two plots denotes a significant difference between the two medians as proposed by Chambers et al. (1983).

the high inter-annual variability in flowering of orchids is due to dormancy induced by unfavourable weather conditions. Summer drought can cause premature senescence and death of leaves, which results in insufficient reserves of nutrients for the orchids to flower the subsequent year (Wells et al. 1998).

At community scale, no evidence was detected regarding the significance of the number of species between years (Fig. 1A). In addition, species composition differed only by $6 \%$ between consecutive years (Table 1 ). We suppose that rare species vary less in terms of the incidence of flowering than abundant species, and thus can be maintained between years. As a result, we can distinguish two different strategies, i.e. high numbers of individuals combined with a high incidence of inter-annual fluctuations (abundant species) and few individuals combined with a low incidence of inter-annual fluctuations (rare species). Similarly, Lavergne et al. (2004) evidenced 
that narrow endemic plants were locally persistent, despite the fact that they produced fewer flowers than their widespread congeners. The persistence of rare species could be related to a better success in reproduction or establishment (Simon and Hay 2003; Byers and Meagher 1996).

\section{Inter-annual variability in flowering at species level}

We evidenced that species responded differently in terms of orchid presence and similarity index (Fig. 2). We attributed this to the disparity of traits between species. The results indicated that the similarity index seems to be negatively related to the duration of flowering. Increasing the flowering duration can lead to an increase in the probability of pollination, and thus to an increase of the reproductive success (fruit production). However, according to Primack and Stacy (1998), a cost of fruit production leads to a reduction in flowering probability in subsequent years (in case of Cypripedium acaule). Further analyses need to be carried out, in order to relate reproductive success to traits, as suggested for the nectar presence (Neiland and Wilcock 1998). In particular, our principal component analysis was based on the mean of traits. Traits should be measured locally in order to consider the variability in a trait in individuals and between habitats.

Orchid species can be detected more or less easily. This is probably due to their particular life-state (dormant or flowering state) and species biological traits, e.g. color of the flower and plant height. Our study evidenced a weak probability of presence for Platanthera chlorantha, in contrast to Anacamptis pyramidalis. This can be due to different levels of difficulty in terms of species detection. Platanthera chlorantha has white-greenish flowers, which is more difficult to be detected compared to Anacamptis pyramidalis that has purple flowers. In order to take into account the imperfect detection, we suggest using the capture-recapture model proposed by Kery and Gregg (2004) in future orchid inventories. Such model can be used to calculate the extent to which orchid records are underestimated due to imperfect detection of orchids. However, inventories of at least three years are needed in order to estimate and correct for imperfect detection.

\section{Inter-annual variability in flowering in different habitats}

Our study revealed that, in Mediterranean regions, a one-year-study is insufficient for monitoring orchids. This may be due to the fact that most of orchid species can stay in dormancy during in which flowering does not occur for one to three years (Shefferson et al. 2001; Brzosko 2003; Kery and Gregg 2004; Coates et al. 2006). Regarding the number of years needed to observe $100 \%$ of the species (Fig. 3), we found: shrubland (2 years) $<$ woodland (3 years) < grassland (4 years). We attribute this result to the disparity of microclimate and light availability between habitats. Higher light availability can increase probability of flowering (Diez et al. 2007; Jac- quemyn et al. 2010). Stable microclimatic conditions, e.g. a warm winter or fresh summer, can favour population performance and avoid dormancy of flowering (Pfeifer et al. 2006). The two factors antagonistically act in the case of grassland and woodland toward probability in flowering. In grassland, there is high light availability, but the microclimatic condition tends to be unstable. On the contrary, in woodland, light availability is low, but the microclimate is more regulated than in open habitat. For example, because of the tree canopy closure, the seasonal variation of air and soil temperature tend to be less contrasted under tree clusters than in open areas (Morecroft et al. 1998; Mao et al. 2013). Therefore, a trade-off effect between microclimate and light availability may exist in both grassland and woodland, thus resulting in higher numbers of years needed to observe $100 \%$ of the species ( $\geq 3$ years). Compared to grassland and woodland, an intermediate condition of light availability and microclimate exists in shrubland, resulting in a lower number of years needed to observe all of the species.

\section{Conclusion and perspectives}

This study showed that in Mediterranean context, climate affects the inter-annual variability of orchid flowering. We evidenced a species-based response in regard to orchid presence. The number of years needed to observe $100 \%$ of species diverged between habitats and last from two to four years. As a result, we suggest that further studies use data collected over periods of a minimum of two years. Species and habitat should be considered equally important when interpreting results.

In the future, relationships between species-specific traits of orchids (e.g. strategies of rare species versus abundant species) and inter-annual variability of flowering need to be better understood in order to enhance the conservation of orchids. Capture-recapture models of orchids, which can take into account imperfect detection, will be a promising tool when characterizing the temporal dynamics of orchid communities.

\section{Acknowledgements}

This study was funded by the Languedoc-Roussillon region, France and a CIFRE convention (No. 187/2011) between the French National Association for Research and Technology (ANRT) and Biotope. We are grateful to the people who helped during fieldwork, including F. Corbion, P. Dabin, F. Dabonneville, G. Delvare, B. Delprat, J. Demarque, T. Disca, P. Escudié, P. Feldmann, F. Geniez, M. Geniez, D. Gruffat, J.-Y. Guillosson, L. Guillosson, T. Guillosson, J.-P. Hervy, M. Imbert, T. Lafranchis, P. Martin, F. Melki, T. Menut, M. Nicole, J. Pommet, S. Roux-Viljoen, G. Soupart, J.-C. Stahl, G. Toreilles and M. Zimmermann. 


\section{REFERENCES}

Archaux F, Camaret S, Dupouey JL, Ulrich E, Corket E, Bourjot L, Brethes A, Chevalier R, Dobremez JF, Dumas Y, Dume G, Foret M, Forgeard F, Lebert Gallet M, Picard JF, Richard F, Savoie JM, Seytre L, Timbal J, Touffet J (2009) Can we reliably estimate species richness with large plots? An assessment through calibration training. Plant Ecol 203: 303-315.

Barnosky AD, Matzke N, Tomiya S, Wogan GOU, Swartz B, Quental TB, Marshall C, McGuire JL, Lindsey EL, Maguire KC, Mersey B, Ferrer EA (2011) Has the Earth's sixth mass extinction already arrived? Nature 471: 51-57.

Bournérias M, Prat D (2005) Les Orchidées de France, Belgique et Luxembourg (2nd ed.). Biotope Mèze (collection Parthénope), Paris, France.

Brzosko E (2003) The dynamics of island populations of Platanthera bifolia in the Biebrza National Park (NE Poland). Ann Bot Fennici 40: 243-253.

Byers DL, Meagher TR (1997) A comparison of demographic characteristics in a rare and a common species of Eupatorium. Ecol Appl 7: 519-530.

Chambers JM, Cleveland WS, Kleiner B, Tukey PA (1983) Graphical Method for Data Analysis. Duxbury Press, Boston, Massachusetts.

Coates F, Lunt ID, Tremblay RL (2006) Effects of disturbance on population dynamics of the threatened orchid Prasophyllum correctum DL Jones and implications for grassland management in south-eastern Australia. Biol Cons 129: 59-69.

Cribb PJ, Kell SP, Dixon KW, Barrett RL (2003) Orchid conservation: a global perspective. In: Dixon KW, Kell SP, Barrett RL, Cribb PJ (eds) Orchid Conservation. Natural History Publications, Kota Kinabalu, pp. 113-136.

Debussche M, Escarré J (1983) Carte des Isohyètes Interannuelles dans le Montpellierais. C.E.P.E., Montpellier, France.

Diez JM, Pulliam HR (2007) Hierarchical analysis of species distribution and abundance across environmental gradients. Ecology 88: 3144-3152.

Dusak F, Prat D (2010) Atlas des orchidées de France. Biotope Mèze (collection Parthénope), Muséum National d'Histoire Naturelle, Paris, France.

Giorgi F, Lionello P (2008) Climate change projections for the Mediterranean region. Glob Planet Chang 63: 90-104.

Hrivnak R, Gomory D, Cvachova A (2006) Inter-annual variability of the abundance and morphology of Dactylorhiza majalis (Orchidaceae-Orchidae) in two permanent plots of a mire in Slovakia. Phyton (Horn). 46: 27-44.

Husson F, Josse J, Le S, Mazet J (2007) FactoMineR: Factor analysis and data mining with $\mathrm{R}$. R package version 1.04.

Hutchings MJ (2010) The population biology of the early spider orchid Ophrys sphegodes Mill. III. Demography over three decades. J Ecol 98: 867-878.

IPCC (2007) Climate Change 2007: The physical science basis contribution of working group I to the fourth assessment report of the intergovernmental panel on climate change. Cambridge University Press, Cambridge.

Jaccard P (1901) Etude comparative de la distribution florale dans une portion des Alpes et du Jura. Bull. Soc. Vaudoise des Sc Nat 37: $547-579$.

Jacquemyn H, Brys R, Hermy M, Willems JH (2005) Does nectar reward affect rarity and extinction probabilities of orchid species? An assessment using historical records from Belgium and the Netherlands. Biol Cons 121: 257-263.

Jacquemyn H, Brys R, Hermy M, Willems JH (2007) Long-term dynamics and population viability in one of the last popula- tions of the endangered Spiranthes spiralis (Orchidaceae) in the Netherlands. Biol Cons 134: 14-21.

Jacquemyn H, Brys R, Jongejans E (2010) Size-depending flowering and costs of reproduction affect population dynamics in a tuberous perennial woodland orchid. J Ecol 98: 1204-1215.

Kati V, Devillers P, Dufrene M, Legakis A, Vokou D, Lebrun P (2004) Testing the value of six taxonomic groups as biodiversity indicators at a local scale. Cons Biol 18: 667-675.

Kery M, Gregg KB (2004) Demographic analysis of dormancy and survival in the terrestrial orchid Cypripedium reginae. J Ecol 92: 686-695.

Kindlmann P, Balounova Z (1999) Flowering regimes of terrestrial orchids: unpredictability or regularity? J Veg Sci 10: 269-273.

Kindlmann P (2003) Irregular flowering regimes in orchids. Lankesteriana 7: 77-80.

Kull T, Hutchings MJ (2006) A comparative analysis of decline in the distribution ranges of orchid species in Estonia and the United Kingdom. Biol Cons 129: 31-39.

Mao Z, Jourdan C, Bonis ML, Pailler F, Rey H, Saint-André L, Stokes A (2013) Modelling root demography in heterogeneous mountain forests and applications for slope stability analysis. Plant and Soil 363: 357-382.

Morecroft MD, Taylor ME, Oliver HR (1998) Air and soil microclimates of deciduous woodland compared to an open site. Ag Forest Meteor 90: 141-156.

Lavergne S, Thompson JD, Garnier E, Debussche M (2004) The biology and ecology of narrow endemic and widespread plants: a comparative study of trait variation in 20 congeneric pairs. Oikos 107: 505-518.

Neiland MRM, Wilcock CC (1998) Fruit set, nectar reward, and rarity in the Orchidaceae. Am J Bot 85: 1657-71.

Oien DI, Moen A (2002) Flowering and survival of Dactylorhiza lapponica and Gymnadenia conopsea in the Solendet Nature Reserve, central Norway. In: Kindlmann P, Willems JH, Whigham DF (eds) Trends and Fluctuations and Underlying Mechanisms in Terrestrial Orchid Populations Backhuys Publisher, Leiden, the Netherlands, pp. 3-22.

Parmesan C (2006) Ecological and evolutionary responses to recent climate change. Annu Rev Ecol Evol Syst 37: 637-669.

Pfeifer M, Wiegand K, Heinrich W, Jetschke G (2006) Long-term demographic fluctuations in an orchid species driven by weather: implications for conservation planning. J Appl Ecol 43: 313-324.

Pfeifer M, Passalacqua NG, Bartram S, Schatz B, Croce A, Carey PD, Kraudelt H, Jeltsch F (2011) Conservation priorities differ at opposing species borders of a European orchid. Biol Cons 143: 2207-2220.

Primack R, Stacy E (1998) Cost of reproduction in the pink lady's slipper orchid (Cypripedium acaule, Orchidaceae): an eleven-year experimental study of three populations. Am J Bot 85: $1672-1679$

R Development Core Team (2010) R: A language and environment for statistical computing (R Foundation for Statistical Computing, Vienna, Austria).

Schatz B, Geniez P (2011) Les orchidées, un patrimoine à préserver. In: Pietrasanta Y, Schatz B (eds), Le Génie de la nature. Biotope, Mèze, France (Collection Parthénope), pp. 26-47.

Schatz B, Gauthier P, Debussche M, Thompson J (2013) A decision tool for listing species for protection on different geographic scales and administrative levels. J Nature Cons (in press).

Shefferson RP, Sandercock BK, Proper J, Beissinger SR (2001) Estimating dormancy and survival of a rare herbaceous perennial using mark-recapture models. Ecology 82: 145-156. 
Sieg CH, King RM (1995) Influence of environmental-factors and preliminary demographic-analyses of a threatened orchid, Platanthera-praeclara. Am Midl Nat 134: 307-323.

Simon MF, Hay JDV (2003) Comparison of a common and rare species of Mimosa (Mimosaceae) in Central Brazil. Austr Ecol 28: $315-326$

Sirami C, Nespoulous A, Cheylan JP, Marty P, Hvenegaard GT, Geniez P, Schatz B, Martin JL (2010) Long-term anthropogenic and ecological dynamics of a Mediterranean landscape: Impacts on multiple taxa. Land Urb Plan 96: 214-223.

Tali K (2002) Dynamics of Orchis ustulata populations in Estonia. In: Kindlmann P, Willems JH, Whigham DF (eds) Trends and Fluctuations and Underlying Mechanisms in Terrestrial Orchid Populations Backhuys Publisher, pp. 33-42.

Tamm CO (1991) Behaviour of some orchid populations in a changing environment. Observations on permanent plots, 1943-1990. In: Wells TCE, Willems JH (eds) Population Ecology of Terrestrial Orchids. SPB Academic Publishers, The Hague, the Netherlands, pp. 1-13.

Thuiller W, Lavergne S, Roquet C, Boulangeat I, Lafourcade B, Araujo MB (2011) Consequences of climate change on the tree of life in Europe. Nature 470: 531-534.

Wells TCE, Rothery P, Cox R, Bamford S (1998) Flowering dynamics of Orchis morio L. and Herminium monorchis (L.) R.Br. at two sites in eastern England. Bot J Linn Soc 126: 39-48.

Whigham DF, Willems JH (2003) Demographic studies and life-history strategies of temperate terrestrial orchids as a basis for conservation. In: Dixon KW, Kell SP, Barrett RL, Cribb PJ (eds) Orchid Conservation. Natural History Publications, Kota Kinabalu, Sabah, Borneo, pp. 137-158.

\section{SUPPLEMENTARY MATERIALS}

Table S1 List of the orchid species studied with the abbreviated names (Abb) and the number of locations where the species was recorded for each habitat (Grassland, Shrubland, Woodland).

\begin{tabular}{|c|c|c|c|c|c|}
\hline Species & Abb & Grassland & Shrubland & Woodland & Total \\
\hline Anacamptis fragrans & Afr & 2 & 0 & 1 & 3 \\
\hline Anacamptis laxiflora & Ala & 1 & 0 & 0 & 1 \\
\hline Anacamptis morio & Amo & 5 & 0 & 0 & 5 \\
\hline Anacamptis pyramidalis & Apy & 10 & 7 & 5 & 22 \\
\hline Cephalanthera damasonium & Cda & 1 & 2 & 3 & 6 \\
\hline Cephalanthera longifolia & Clo & 1 & 2 & 3 & 6 \\
\hline Cephalanthera rubra & Cru & 0 & 1 & 1 & 2 \\
\hline Coeloglossum viride & Cvi & 1 & 0 & 0 & 1 \\
\hline Cypripedium calceolus & Cca & 0 & 0 & 1 & 1 \\
\hline Dactylorhiza elata & Del & 0 & 0 & 1 & 1 \\
\hline Dactylorhiza fuchsii & Dfu & 1 & 3 & 4 & 8 \\
\hline Dactylorhiza occitanica & Doc & 1 & 0 & 0 & 1 \\
\hline Dactylorhiza sambucina & Dsa & 1 & 0 & 1 & 2 \\
\hline Epipactis atrorubens & Eat & 0 & 0 & 2 & 2 \\
\hline Epipactis helleborine & Ehe & 0 & 1 & 4 & 5 \\
\hline Epipactis microphylla & Emi & 0 & 0 & 1 & 1 \\
\hline Goodyera repens & Gre & 0 & 0 & 1 & 1 \\
\hline Gymnadenia conopsea & Gco & 3 & 0 & 1 & 4 \\
\hline Himantoglossum hircinum & Hhi & 4 & 4 & 2 & 10 \\
\hline Himantoglossum robertianum & Hro & 1 & 1 & 1 & 3 \\
\hline Limodorum abortivum & Lab & 1 & 3 & 3 & 7 \\
\hline Neotinea ustulata & Nus & 3 & 0 & 1 & 4 \\
\hline Neottia nidus-avis & Nni & 0 & 0 & 2 & 2 \\
\hline Neottia ovata & Nov & 2 & 1 & 4 & 7 \\
\hline Ophrys apifera & Oap & 4 & 1 & 3 & 8 \\
\hline Ophrys araneola & Oar & 1 & 0 & 1 & 2 \\
\hline Ophrys aveyronensis & Oav & 1 & 0 & 0 & 1 \\
\hline Ophrys aymonini & Oay & 1 & 0 & 1 & 2 \\
\hline Ophrys bilunulata & Obi & 0 & 1 & 0 & 1 \\
\hline Ophrys insectifera & Oin & 1 & 1 & 1 & 3 \\
\hline Ophrys lupercalis & Olu & 0 & 2 & 0 & 2 \\
\hline
\end{tabular}




\begin{tabular}{|c|c|c|c|c|c|}
\hline Species & Abb & Grassland & Shrubland & Woodland & Total \\
\hline Ophrys lutea & Olut & 2 & 1 & 0 & 3 \\
\hline Ophrys massiliensis & Omas & 0 & 1 & 0 & 1 \\
\hline Ophrys occidentalis & Ooc & 1 & 1 & 1 & 3 \\
\hline Ophrys passionis & Opa & 3 & 0 & 0 & 3 \\
\hline Ophrys scolopax & Osc & 2 & 4 & 1 & 7 \\
\hline Ophrys sulcata & Osu & 1 & 0 & 0 & 1 \\
\hline Ophrys virescens & Ovi & 1 & 0 & 1 & 2 \\
\hline Orchis anthropophora & Oan & 3 & 3 & 4 & 10 \\
\hline Orchis mascula & Oma & 4 & 3 & 3 & 10 \\
\hline Orchis militaris & Omi & 2 & 0 & 2 & 4 \\
\hline Orchis provincialis & Opr & 0 & 0 & 1 & 1 \\
\hline Orchis purpurea & Opu & 4 & 2 & 1 & 7 \\
\hline Orchis simia & Osi & 2 & 4 & 2 & 8 \\
\hline Platanthera bifolia & $\mathrm{Pbi}$ & 4 & 3 & 2 & 9 \\
\hline Platanthera chlorantha & Pch & 1 & 2 & 3 & 6 \\
\hline Spiranthes spiralis & Ssp & 1 & 1 & 1 & 3 \\
\hline
\end{tabular}

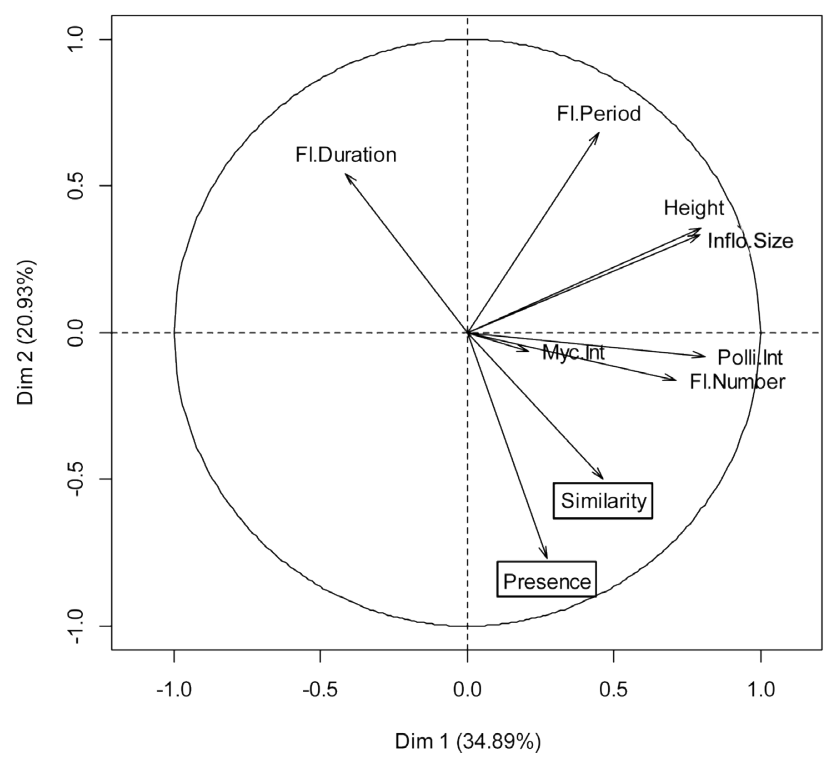

Fig. S1 Principal component analysis of the similarity index, probability of presence and species traits. Similarity = Similarity index, Presence $=$ probability of presence, Polli.Int $=$ number of species of pollinators, Myc.Int = number of mycorrhizal symbionts, Height $=$ plant height, Inflo.Size $=$ inflorescence size, Fl.Number $=$ number of flowers, Fl.Duration = duration of the flowering period, Fl.Period $=$ flowering duration . 


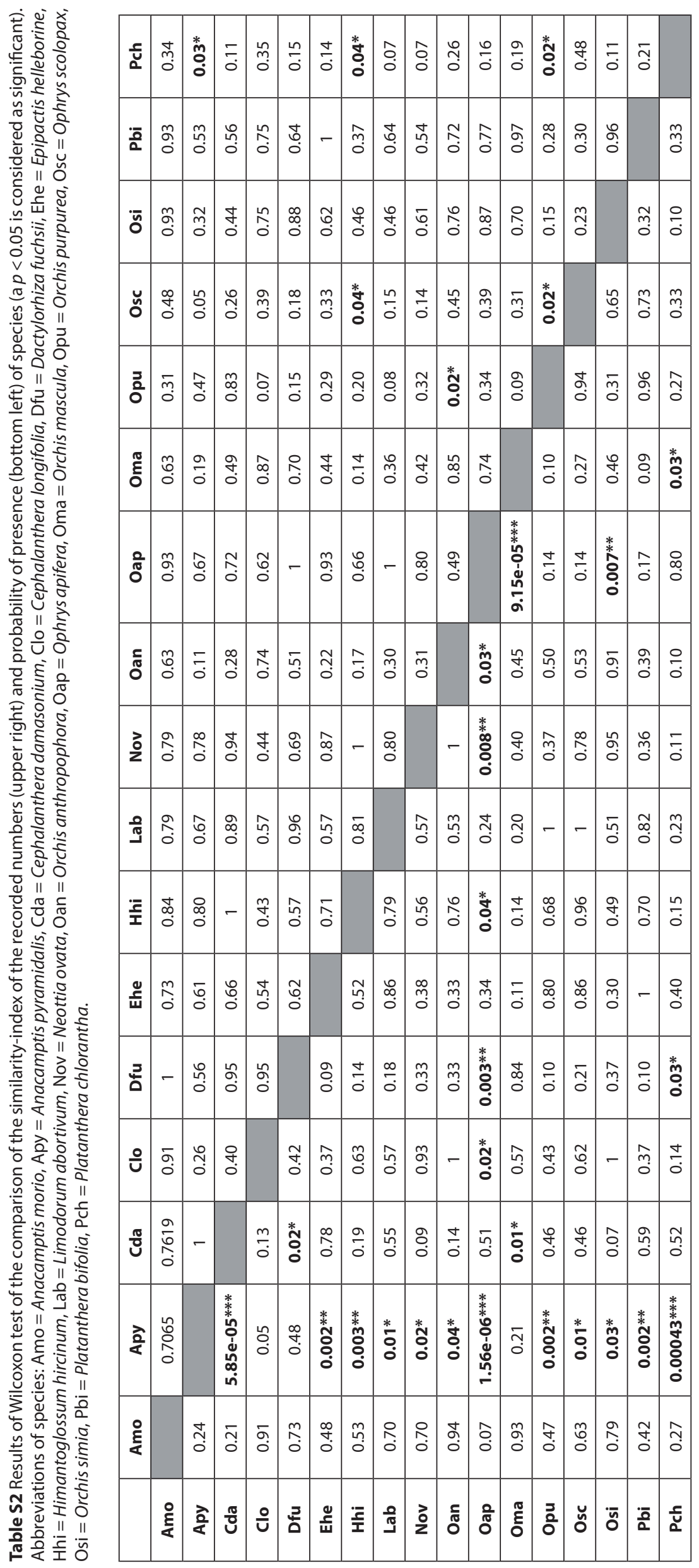

